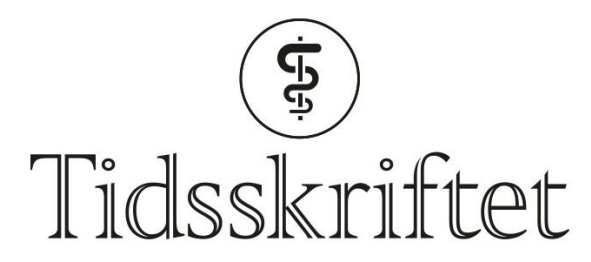

DEN NORSKE LEGEFORENING

\title{
Store mangler i rapportering av studier
}

FRA ANDRE TIDSSKRIFTER

KETIL SLAGSTAD

Tidsskriftet

Resultatene av halvparten av alle kliniske studier i EU blir ikke innrapportert etter at studien er avsluttet.

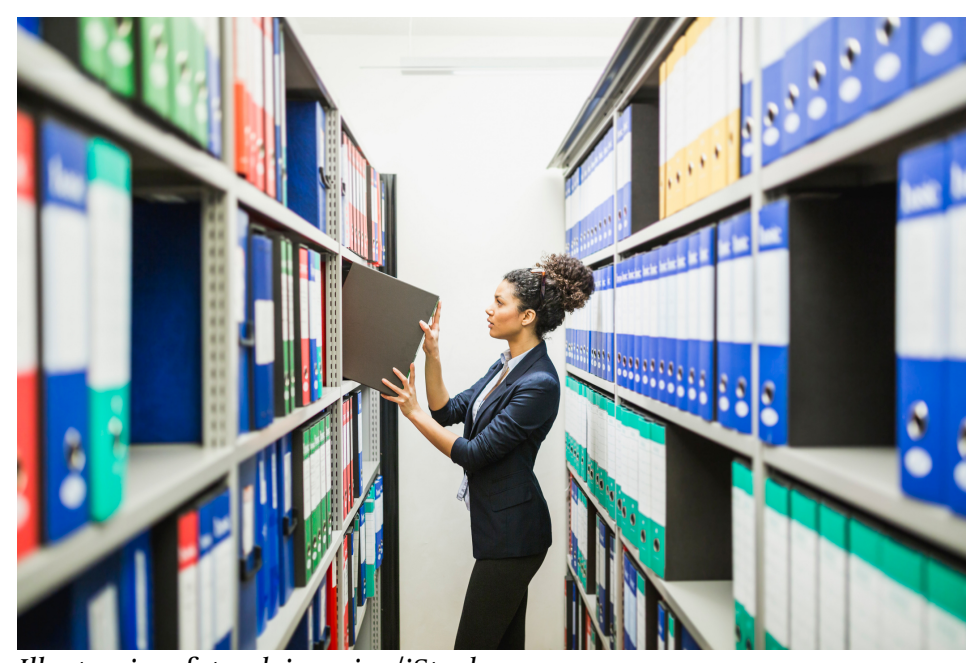

Illustrasjonsfoto: deimagine/iStock

Ifølge EUs regelverk skal alle medisinske intervensjonsstudier registreres i European Union Clinical Trials Register (EUCTR). Studieresultatene skal rapporteres inn til de europeiske legemiddelmyndighetene innen ett år etter studieslutt. Resultatene blir deretter offentliggjort i registeret innen to uker. I en studie publisert i tidsskriftet $B M J$, undersøkte forfatterne om dette kravet blir overholdt (1). Over 7200 studier fra og med 2004 ble inkludert. $90 \%$ av deltagerne i studiene var friske og $10 \%$ var pasienter. To tredeler av studiene var sponset av et legemiddelfirma.

Studieresultatene var innrapportert i bare rundt halvparten av studiene. I studiene som var sponset av et legemiddelfirma, ble resultatene korrekt innrapportert i 68,1\% (95 \% KI 66,7-69,4), mot kun 11,o \% av studiene med ikke-kommersiell sponsor ( 95 \% KI 9,8-12,4). Sponsorene som finansierte mange studier, rapporterte flere studier enn de som finansierte få studier. Det var mange feil og utelatelser i rapporteringen: For $30 \%$ av studiene som var avsluttet, var avslutningsdato ikke fastsatt, noe som gjør det vanskelig å spore om rapporteringskravet var blitt fulgt.

- Disse funnene er nedslående, sier Lars Slørdal, som er professor i farmakologi ved Norges 
teknisk-naturvitenskapelige universitet. - Vi vet at mye klinisk forskning ikke blir publisert, blant annet fordi sponsor bare publiserer det de ønsker å publisere og lar være å publisere uønskede resultater. Et krav om at kliniske forsøk må registreres i databaser, har vært et forsøk på å bøte på dette problemet. Hvis en slik ordning skal fungere, må rapporteringsplikten overholdes, sier Slørdal.

- Den store forskjellen mellom kommersielle og ikke-kommersielle sponsorer var overraskende, og særlig at dette så til de grader gikk i universitetssektorens disfavør, mener Slørdal. - Hvis universitetene skal vokte storsamfunnets interesser på en troverdig måte, kan de ikke selv være «verstinger» innen innrapporteringsrutiner, sier han.

- Det er urovekkende at rapporteringsplikten blir oppfylt for bare rundt halvparten av kliniske studier, til tross for klare kriterier og betydelig oppmerksomhet rundt problemet. Manglende innrapportering og publisering er et stort problem for kunnskapsbasert medisin. Ikke minst er det et svik mot alle pasienter og de som deltar i kliniske studier, sier Slørdal.

\section{LITTERATUR:}

1. Goldacre B, DeVito NJ, Heneghan C et al. Compliance with requirement to report results on the EU Clinical Trials Register: cohort study and web resource. BMJ 2018;362: k3218. [PubMed][CrossRef]

Publisert: 1. november 2018. Tidsskr Nor Legeforen. DOI: 10.4045/tidsskr.18.0764

(C) Tidsskrift for Den norske legeforening 2020. Lastet ned fra tidsskriftet.no 